\title{
Educação Interprofissional transFORMANDO para o SUS
}

\author{
Susane Lindinalva da Silva, Fernando de Lima, Franceline Euzébio Gomes da Silva, Mariana \\ Nathália Gomes de Lima, Gisele Barbosa de Aguiar
}

\section{Resumo}

Introdução: Historicamente no Brasil a formação em saúde direciona-se na perspectiva biomédica de atenção, estreitamente influenciada pela prática curativista, tendo currículos organizados num sentido disciplinar baseado no acúmulo de conhecimento, fragmentando o conhecimento e fortalecendo a utilização de métodos tecnicistas. Essa formação favorece o sistema capitalista na produção de profissionais enquanto reserva de mercado inserido na dicotomia teoria-prática e distante do compromisso entre a academia e os serviços/comunidade, enfraquecendo a resolutividade do Sistema Único de Saúde (SUS). O modelo de formação biomédico favorece exclusivamente as necessidades biológicas dos indivíduos, priorizando uma lógica de ensinoaprendizagem limitante sobre a compreensão do processo de saúde-doença da população e reduzindo o sujeito doente a um órgão, sistema ou doença. A formação uniprofissional torna os futuros profissionais da saúde incapazes de compreender e trabalhar com a integralidade do ser humano. Porém, existe uma alternativa capaz de atender ao cuidado integral onde se enfatiza a interdisciplinaridade, que é a Educação Interprofissional (EIP). A inserção dessa linha pedagógica de dinâmica de trabalho interdisciplinar corrobora com o desenvolvimento da formação profissional de trabalhadores para o SUS numa visão de aprender sobre, para e com a outra área profissional a fim de proporcionar um cuidado integral e humanizado. Objetivos: Descrever a potencialidade do compartilhamento de saberes interprofissionais desde a graduação como incentivo para as mudanças na formação em saúde, tendo como fio condutor o trabalho em equipe como um espaço de aprendizado e diálogo de saberes fortalecendo a integralidade em saúde. Métodos: O presente relato trata-se das vivências interprofissionais de 10 graduandos, dos cursos de ciências biológicas, educação física, enfermagem, nutrição e saúde coletiva a partir de ações de educação e promoção à saúde vinculadas ao Programa Nacional de Reorientação da Formação Profissional em Saúde (PRÓ-SAÚDE) e o Programa de Educação pelo Trabalho para a Saúde (PET-Saúde) em uma escola de ensino fundamental localizada no município de Vitória de Santo Antão-PE, participando 300 crianças e adolescentes, 10 professores da escola além de preceptores e tutores durante o período de agosto a dezembro de 2017. As ações acontecem semanalmente, ás terças-feiras, com propostas educativas com metodologias ativas e construtivas estimulando o protagonismo dos alunos, oportunizando falas e construindo debates reflexivos. Quanto ao aprendizado dos graduandos a partir da construção de ações/intervenções coletivas pautadas na EIP exaltando o trabalho em equipe e despertando um novo trabalhador para o SUS, ressignificando conhecimentos, práticas e posturas sociais, tendo a compreensão de si e do outro como agentes imprescindíveis na afirmação do SUS como patrimônio da classe trabalhadora e propondo ao usuário um cuidado de fato integral como também se desfazendo da métrica acadêmica e dialogando com outros campos disciplinares, firmando a formação acadêmica na integração dos serviços de saúde contemplando as carências advindas da população. Resultados: A articulação dessas iniciativas além de estimular a interação dos docentes e dos discentes com os profissionais e usuários do SUS, através de práticas que perpassam os temas da educação ambiental, como o cuidado com a água, reciclagem e direito à alimentação até educação sexual e desconstrução dos preconceitos de gênero levando em consideração as particularidades de contextos socioculturais do sujeito, ações e relações, numa visão ampla, suscitando o diálogo real com as necessidades da população chave, na construção de um projeto de sociedade inclusivo, democrático e plural, elaborando novos espaços de 
ISSN 2179-6750

aprendizagem, discutindo sobre os papeis sociais, e conscientizando sobre os tipos de opressões que muitas vezes estão culturalmente enraigados. A EIP é uma proposta fundamental por construir em graduandos e profissionais o reconhecimento da complementaridade de saberes para o cuidado integral, a complexidade das necessidades da população e também atribuir novos significados para educação e saúde. As atividades do PET promoveram experiências que possibilitaram a produção e a disponibilização de informações em saúde para as crianças e jovens da escola, de maneira lúdica, participativa e o mais importante com o olhar e cuidado de cada graduando, abordando uma linha de trabalho crítica-reflexiva a fim de despertar através das ações educativas, ricas em afetividade e implicação mútua, a busca do empoderamento dos jovens e sua autonomia, relevando a reorientação proporcionada pelas ações do PET nas relações interpessoais e interprofissionais, usufruindo de processos formativos para a atuação na saúde pública integrando ensino-serviço-comunidade desconstruindo estereótipos e transformando novos cenários de troca de saberes no intuído de ultrapassar a concepção de educação tradicional e bancária para uma educação popular e libertadora, havendo reflexões que emergiram dessa multiplicidade de atrizes e atores que permaneceram vivas entre as crianças, jovens, equipe de saúde e gestores da escola, fomentando a construção contínua desse espaço cíclico de transformação dos sujeitos. Muitas vezes pensamos que estamos ensinando algo novo ou reconstruindo o aprendizado relacionado a outros assuntos, mas, no entanto aprendemos ainda mais com eles, a forma como são despertados por nossas atividades é indescritivelmente gratificante, o trabalho é prazeroso, pois ver em seus rostos a fisionomia de alegria é extraordinário. Quando olhamos por outra óptica, o projeto propiciou novos laços de interação, seja com aluno ou com os próprios integrantes do PET, ampliando a visão de compreensão a aprendizagem e a prática interprofissional como uma resultante das capacidades de cada um, estabelecendo assim um equilíbrio dinâmico entre a organização do saber e o que fazer, fortalecendo vínculos, identificando temas pertinentes, mediando situações, planejando e executando coletivamente estratégias, perpassando sobre a crítica do processo de trabalho, corresponsabilização e autocrítica. Conclusões: Conforme se rompe com a lógica tradicional de formar trabalhadores em saúde, e é inserido um diálogo inclusivo como a EIP, por exemplo, todos que participam deste processo deparam-se com pretensões e alternativas de aprender a ensinar de maneira mais participativa, recíproca e inovadora, superando o modelo academicista/mecanicista, reafirmando o trabalho em equipe, construindo ativamente o cuidado em saúde, ampliando a humanização, sensibilizando aos conjuntos de determinantes socioculturais, valorizando os direitos sociais e autonomia. A EIP, torna todos que a constroem co-responsáveis pela formação em saúde, acreditando ser realizável e necessário (re)conhecer as dinâmicas do saber, criar e dar-se em saúde. Por fim, consideramos que quando impulsionamos a interdisciplinaridade, é preciso considerar todos os ângulos, inclusive o ainda não descoberto e revelado para que então teçamos um novo caminho para o acontecer no SUS. A EIP é a mudança de paradigma da formação em saúde por construir profissionais generalistas, humanistas, críticos-reflexivos, capazes de atuar em todos os níveis de atenção a saúde, com ações de promoção, prevenção, recuperação e reabilitação, garantindo a integralidade da assistência, despertando o senso de responsabilidade social e compromisso com a cidadania, e não menos importante atendendo à demanda do SUS. As interações interdisciplinaridades oportunizaram situações pedagógicas com inúmeros desafios positivos e negativos que consideramos potencializadoras pela possibilidade dialógica entre as profissões. A horizontalização das decisões representa um poderoso instrumento para formação profissional/social, pois, é um espaço pedagógico que alavanca a inserção dos estudantes nos cenários da prática profissional, permitindo a aproximação e respeito de cada estudante com a realidade de outras categorias, ampliando seu olhar em direção ao processo saúde-doença, envolvendo- se com práticas interdisciplinares, que sem duvidas é um processo duro, lento e cíclico, demandando de amorosidade, respeito e confiança pelo saber do outro. 
ISSN 2179-6750

Descritores: Formação profissional, Relações interprofissionais, Equipe de saúde, Educação em saúde integralidade em saúde 